\title{
Chinese Foreign Direct Investment in Australia: Policy Issues for the Resource Sector
}

\author{
Peter Drysdale \\ Crawford School of Economics and Government \\ The Australian National University \\ and \\ Christopher Findlay \\ School of Economics \\ University of Adelaide
}

\begin{abstract}
The past eighteen months has seen Chinese foreign direct investment (FDI) in the Australian resource sector become an issue of policy interest. There are two big questions that the prospects of a significant rise in FDI from China into the Australian resources sector have raised. Is the surge of FDI into Australian mining and energy consistent with achieving the traditional gains from foreign investment? And are there any particular problems associated with investment from foreign state-owned enterprises or state managed sovereign wealth funds? These are among the questions addressed in this paper. The paper argues that there are no issues that cannot be dealt with under the umbrella of the established test of 'national interest' in managing the growth of Chinese FDI into the Australian minerals sector. It argues that a confusion has been introduced into policy over the questions of state-ownership and supplier-buyer relations in respect of Chinese investments and that clarifying these issues is likely to be important to Australia's capturing the full benefits from the growth of Chinese resources demand and longer term economic and strategic interests in China.
\end{abstract}

Paper for China Economic Journal, June 2009 and the China Update, July 2009 


\section{Chinese Foreign Direct Investment in Australia: \\ Policy Issues for the Resource Sector ${ }^{*}$}

The escalating interest in resource investment worldwide, before the global financial crisis, was driven by the appetite for resources in the rapidly growing Chinese and Indian markets (Streifel, 2006, ABARE 2008). These economies themselves have now emerged as major players in overseas resource investment and development. The global economic crisis has not dampened China’s appetite for investment in Australia’s resource sector and the shortage of international capital has further enhanced the attractiveness of investment alliances with Chinese partners.

The international resource industry was dominated in its early days by North American and European investment, often through vertically integrated operations that incorporated supply of metal products to industrial country markets. This pattern of development changed remarkably around forty years ago as Japan emerged as a major consumer of imported minerals and energy (Drysdale, 1970). At the time, Japanese end-users had little capacity to invest in the huge projects overseas that were needed to service procurement of the resources to fuel Japan's rapid industrialisation (Crawford, Okita et al, 1978). This was the era in which the emergence of the huge independent suppliers of resources to Japan and eventually to the rest of East Asia laid the foundations for the strength and competitiveness of the Australian minerals industry and Australia's leading minerals companies. They became leading world suppliers of a whole range of products, including iron ore, coal, bauxite, alumina, aluminium, copper, nickel, natural gas and uranium to the international market (Drysdale, 1988).

\footnotetext{
* We are indebted to a large number of people for information, advice and assistance in the preparation of this paper. Shiro Armstrong and Darien Williams provided research assistance at the East Asia Bureau of Economic Research (EABER) as did Claire Hollweg and Uwe Kaufmann at the School of Economics at the University of Adelaide and they deserve our special thanks. Earlier versions of the paper have been presented at the Crawford School of Economics and Government, the ANU's China Forum, the China Energy Research Institute and Peking University’s Center for China Economic Research. We are grateful to colleagues in all those forums and, to officials at the Australian Treasury, for valuable feedback. We are especially grateful to Ligang Song, Ross Garnaut, Shiro Armstrong and colleagues in the Crawford School's seminar series who provided comments on various drafts. We are, of course, alone responsible for whatever deficiencies it continues to contain.
} 
China and India offer opportunity on a scale that already dwarfs established markets in Japan and the rest of Asia for the expansion of resource supplies from Australia, and a huge growth in the Australian industry. As in the past, realising the opportunity will depend not only on gearing up investment from Australian and foreign firms who are already significant players in the international resource business but will encourage and require a large injection of additional capital from new investors, both foreign and domestic (Albanese, 2008; Kloppers, 2008).

Australia has perhaps the most efficient mining sector in the world. This is importantly due to its openness to foreign investor competition and participation, because that brings with it, and fosters, the technology, management know-how and market links that are essential ingredients in the development of a world class, internationally competitive industry. Australia, therefore, has a long record, and a strong policy regime, characterised by openness towards foreign investment in its resource industries, despite the fact that, by one measure, Australia is ranked among the most restrictive among OECD countries in its treatment of FDI more generally (Stoeckel, 2008; Kearney, 2007) ${ }^{1}$. There was some retreat from openness to investment in the resource sector that created uncertainties about the resource investment climate during the last global resource boom during the 1970s (McKern, 1976; Caves, 1978; Hanratty, 1996). The change in policy tone was encouraged by a big shift in the relative price of resource goods in those years and reflected the emergence of a measure of resources nationalism. Although the period of retreat was relatively short-lived, consumers sought alternative supplies elsewhere and, as markets eased, Australian policy towards foreign investment in the resource and energy sector opened up once again.

The collapse of commodity prices, coinciding with a sharp global recession, has not seen the abatement of interest by Chinese and some other investors in Australian resources this time round. Indeed, established and aspiring producers have turned to Chinese investors for equity and financial support as bank and other capital has dried up.

\footnotetext{
${ }^{1}$ These indexes measure the formal requirements for investment approval, and these requirements will have an effect in deterring investment, although not necessarily in investment approval outcomes. On this latter measure Australia might rank as a less restrictive regime.
} 
Though in the early stages of industrialisation, China and India are both already sources of substantial international capital (McKinsey, 2008). They have been active candidates for growing investment in the Australian resource industry, because of their capacity to mobilise capital for direct as well as indirect investment in this highly prospective sector in the world economy and because firms that consume raw materials and policymakers in those countries remain anxious to secure resource supplies over the long term even though demand for some key commodities has eased in the short term.

This is the background and context in which there is growing discussion of Australian policies towards Chinese foreign investment in Australia’s resource sector.

\section{The argument}

The rise of Chinese and Indian demand for resources continues to drive growth in investment in the resources sector in Australia. The scale alone of the accompanying surge in FDI prompts anew questions about the role of FDI.

In addition, both China and India, in different political contexts, give the state a large role in their economies and a big share of their outward investment is channelled through state-owned enterprises, state-owned banks or sovereign wealth funds.

Australia and most other developed countries have spent the past couple of decades convincing their voters that the private sector, not government, should take the lead in managing most businesses. The global financial crisis has seen a retreat from this philosophy but this has not diminished questioning of the role of the state in foreign investment activities. At the same time, the developed countries continue to stress the important benefits that come from foreign investment and to run open regimes towards foreign investment, both direct and indirect. When confronted by governmentcontrolled foreign investment, it might seem that one of these propositions has to give (Thirlwell, 2008).

So there are two big questions that the prospects of a significant rise in foreign direct investment (FDI) from China into the Australian resources sector have raised. Is the surge of FDI into Australian mining and energy consistent with achieving the 
traditional gains from foreign investment? And are there particular problems associated with investment from foreign state-owned enterprises or state managed sovereign wealth funds? These are the two central questions that we shall address in this paper.

There are corollary questions. FDI from state-owned enterprise is conceptually different in character and effect from portfolio (indirect) investment out of sovereign wealth funds. This distinction may be blurry at the edges. A minority stake by a single investor in a project might be accompanied by control through participation in the board of the firm or other arrangements that constrain the management of the project. And policy authorities may apply different measures in terms of the share of ownership in judging the distinction between direct and portfolio investment ${ }^{2}$. But, in principle the distinction between passive investment by a portfolio investor and direct foreign investment is clear enough. What are the implications of these distinctions? How important is the extent of control of a project by the foreign partner?

Australia’s Treasurer, Wayne Swan, has said:

We usually welcome and encourage some participation by the buyer, because that offers the buyer some security of supply and the seller some stability in the market. But we need to ensure that investment is consistent with Australia's aim of ensuring that decisions continue to be driven by commercial considerations and that Australia remains a reliable supplier in the future to all current and potential trading partners.....(I)t follows that as the proposed participation by a consumer of the resource increases to the point of control over pricing and production, and especially where the resource in question is already developed and forms a major part of the total resource, or where the market disciplines applying to public companies are absent, I will look more carefully at whether the proposal is in Australia's national interest. ${ }^{3}$

Apart from the extent of control, how important is the home country's policy regime? State-owned enterprises operate under different policy regimes in different countries. The regime under which Swedish state-owned enterprise operates may be different from that under which Chinese or Indian state-owned enterprise operates. Do these differences affect the impact of investment from these different sources? Further, the

\footnotetext{
${ }^{2}$ The Australian policy authorities in the past would appear to have judged a share in ownership of 15 per cent to constitute a significant direct investment, although a much lower share, of around or under 10 per cent, has attracted policy interest. Technically a foreign stake of 10 per cent in an investment qualifies that investment for inclusion in the data for FDI.

${ }^{3}$ Wayne Swan, Australia, China and This Asian Century, Speech to the Australia-China Business Council, Melbourne, 4 July 2008
} 
regime under which state-owned enterprises operate changes over time, and it is clearly changing in China. Do these changes need to inform the strategy that host countries might adopt towards FDI from this source?

These are some of the questions that will be discussed in the paper that follows.

First, there is a brief review of the role of FDI in Australia and the Australian resource sector, including an assessment of the rise of Chinese interests and China's economic relationship with Australia. Then we set out the issues for managing a regime that captures the gains from FDI. We ask are there other issues that need to be considered in the case of Chinese FDI. We examine the role of sovereign wealth funds. We conclude with observations about the implications for Australian policy, as well as how Australian policy strategies might play into policy strategies in China and elsewhere.

\section{Role of FDI in the Australian resource sector and China}

FDI plays a particularly important role in the Australian resources sector. Mining accounts for almost one quarter of all FDI in Australian industry, with the accumulated stock of foreign investment amounting to over \$A92 billion in 2007 (ABS, 2009). In the same year, FDI in manufacturing was estimated to be \$A67.7 billion (around 18 per cent) and in services about \$A190 billion. FDI has played a key role in the growth of the resources sector, especially over the last half decade or so, when the annual growth of FDI in the mining sector averaged more than 10 per cent a year (in 2007 there was an increase of 15 per cent).The confidence in Australia's investment environment has been a crucial element in Australia's ability to attract foreign investment into its resources sector and to take advantage of burgeoning opportunities in the international markets for raw materials, notably in China. Foreign investment plays a key role not only in delivering resource supplies to international markets, but also in discovering and proving resource reserves and assets. Without openness to foreign investor participation in the industry, there would be limited willingness to undertake the investment in exploration and development of resources in which FDI has played such an important role. China is already participating actively in the proving of resource deposits (AFR, 2008, 15 August). More than four fifths of the 
investment in offshore petroleum and gas exploration and over one half of the investment in the exploration and assessment of other minerals that underpins production in these industries today were undertaken by foreign investors (Hartley, 1984; ABARE, 2007).

FDI has accounted for more than one third of capital formation in all Australian industry since the turn of the century; in mining and resources it has accounted for almost half, and in some years a much higher proportion, of total capital formation in the sector. Importantly, foreign investors have played a similarly prominent role in capturing export markets, and account for a growing share of minerals exports (ABS, 2004).

Foreign and domestic firms are established and highly competitive suppliers of resources to global markets but China has emerged as far and away the fastest growing market for output from the industry, especially for iron ore and natural gas, in the last decade.

China is already Australia's largest overall trading partner and the largest buyer of a range of Australian raw material exports. Japan remains Australia's largest export market, but it can be confidently forecast that China will replace Japan as our largest export market within the next half decade or less (Drysdale, 2008). ${ }^{4}$ The transformation of China's role in the structure of Australia's global merchandise trade is set out in Tables 1-3.

China is our largest market for iron ore, copper, wool and cotton, and a major and growing market for natural gas. Commodity exports from Australia to China grew at 17 per cent in 2007 and have averaged 19 per cent annual growth over the last decade. Export growth to China has remained important through the global crisis. The trade relationship with China is but one element in what has every prospect of becoming Australia's most important economic relationship overall, bar none. While global FDI flows fell by 20 per cent in 2008, Chinese outflows doubled, to an estimated US\$41 billion (Davies, 2009). China's direct investment share is likely to continue to rise. China's direct investment in Australia is said to have risen to US\$1.4 billion in the first

\footnotetext{
${ }^{4}$ It is likely that this will occur sooner (in the coming year or two) because of the sharp lift in the relative growth of China compared with other markets in the global economic crisis.
} 
quarter of 2008. If that trend were to continue. FDI is a very important, but it is only one dimension of the growing importance of the Chinese economy to Australia and other countries in the world economy.

Although Australia was the destination for some of China's largest early post-reform foreign direct investments - the Channar iron ore project and Portland aluminium project in the 1980s - China remains a relatively small player in Australian investment. Table 4 describes the current scale and structure of Chinese investment across the Australian economy. 
Table 1 Australia's Total Merchandise Trade, by Trading Partner (per cent)

\begin{tabular}{|c|c|c|c|c|c|c|c|c|c|c|c|c|c|c|c|c|c|c|c|}
\hline & 1990 & 1991 & 1992 & 1993 & 1994 & 1995 & 1996 & 1997 & 1998 & 1999 & 2000 & 2001 & 2002 & 2003 & 2004 & 2005 & 2006 & 2007 & 2008 \\
\hline Japan & 23.2 & 22.8 & 21.8 & 22.0 & 21.2 & 19.2 & 16.6 & 16.8 & 16.5 & 16.1 & 16.3 & 16.2 & 15.4 & 15.1 & 15.0 & 15.5 & 14.6 & 14.0 & 15.7 \\
\hline China & 2.6 & 3.1 & 3.7 & 4.2 & 4.7 & 4.7 & 5.2 & 5.2 & 5.2 & 5.7 & 6.6 & 7.5 & 8.6 & 9.8 & 11.2 & 12.7 & 13.5 & 14.8 & 15.2 \\
\hline USA & 16.8 & 16.7 & 15.4 & 14.6 & 14.7 & 14.3 & 14.8 & 14.6 & 16.2 & 15.7 & 15.0 & 13.9 & 14.0 & 12.6 & 11.6 & 10.4 & 10.2 & 9.5 & 8.7 \\
\hline ROK & 4.4 & 4.5 & 4.6 & 5.0 & 4.9 & 5.6 & 6.2 & 5.8 & 5.5 & 5.4 & 6.1 & 5.9 & 6.0 & 5.4 & 5.4 & 5.5 & 5.7 & 5.5 & 5.6 \\
\hline Singapore & 3.7 & 4.1 & 4.5 & 3.9 & 4.1 & 4.3 & 3.8 & 3.8 & 3.2 & 4.4 & 4.2 & 3.9 & 3.7 & 3.3 & 3.7 & 4.3 & 4.5 & 4.1 & 5.0 \\
\hline UK & 5.1 & 4.6 & 4.9 & 5.1 & 4.8 & 4.8 & 5.0 & 4.6 & 5.7 & 4.9 & 4.7 & 4.8 & 4.6 & 5.4 & 4.2 & 3.8 & 4.2 & 4.2 & 4.3 \\
\hline $\mathrm{NZ}$ & 4.8 & 4.7 & 5.0 & 5.4 & 5.9 & 6.0 & 6.0 & 5.9 & 5.1 & 5.7 & 4.9 & 5.0 & 5.2 & 5.5 & 5.4 & 4.9 & 4.2 & 4.4 & 3.8 \\
\hline Thailand & 1.1 & 1.2 & 1.6 & 1.6 & 1.7 & 1.8 & 1.8 & 1.8 & 1.6 & 1.9 & 2.1 & 2.1 & 2.3 & 2.5 & 2.6 & 3.0 & 3.1 & 3.5 & 3.5 \\
\hline India & 0.9 & 0.9 & 1.0 & 1.1 & 1.0 & 1.1 & 1.2 & 1.4 & 1.5 & 1.2 & 1.1 & 1.3 & 1.4 & 1.8 & 2.5 & 2.8 & 3.0 & 3.0 & 3.4 \\
\hline Germany & 4.1 & 3.9 & 3.8 & 3.6 & 3.9 & 4.2 & 3.7 & 3.4 & 3.9 & 3.8 & 3.2 & 3.4 & 3.6 & 3.9 & 3.7 & 3.4 & 3.1 & 3.1 & 3.0 \\
\hline ROW & 33.3 & 33.3 & 33.8 & 33.5 & 33.2 & 34.0 & 35.8 & 36.8 & 35.6 & 35.2 & 35.7 & 36.1 & 35.2 & 34.6 & 34.7 & 33.7 & 33.9 & 33.9 & 31.9 \\
\hline Total (\$b) & 84.2 & 103.3 & 113.8 & 125.0 & 132.7 & 149.0 & 155.2 & 168.1 & 185.6 & 188.2 & 227.1 & 240.1 & 247.0 & 237.8 & 258.8 & 294.7 & 339.7 & 356.1 & 448.9 \\
\hline
\end{tabular}

Source: ABS Cat. No. 5368.0 Tables 14a) and 14b) 
Table 2 Australia's Merchandise Exports, by Trading Partner (per cent)

\begin{tabular}{|c|c|c|c|c|c|c|c|c|c|c|c|c|c|c|c|c|c|c|c|}
\hline & 1990 & 1991 & 1992 & 1993 & 1994 & 1995 & 1996 & 1997 & 1998 & 1999 & 2000 & 2001 & 2002 & 2003 & 2004 & 2005 & 2006 & 2007 & 2008 \\
\hline Japan & 26.6 & 27.6 & 25.3 & 24.9 & 24.7 & 23.1 & 20.2 & 19.9 & 19.6 & 19.2 & 19.8 & 19.4 & 18.6 & 18.2 & 18.9 & 20.5 & 19.8 & 19.0 & 22.6 \\
\hline China & 2.6 & 2.8 & 3.2 & 3.7 & 4.4 & 4.4 & 5.0 & 4.7 & 4.3 & 4.7 & 5.5 & 6.2 & 7.0 & 8.4 & 9.4 & 11.6 & 12.4 & 14.1 & 14.8 \\
\hline ROK & 6.0 & 6.3 & 6.3 & 7.0 & 7.3 & 8.5 & 9.5 & 8.0 & 6.9 & 7.2 & 8.2 & 7.8 & 8.4 & 7.5 & 7.8 & 7.9 & 7.5 & 8.0 & 8.3 \\
\hline India & 1.2 & 1.2 & 1.4 & 1.5 & 1.4 & 1.5 & 1.6 & 2.0 & 2.4 & 1.7 & 1.7 & 2.0 & 2.1 & 3.1 & 4.6 & 5.0 & 5.4 & 5.5 & 6.1 \\
\hline USA & 11.6 & 10.0 & 8.8 & 8.1 & 7.2 & 6.5 & 6.5 & 7.5 & 9.5 & 9.7 & 10.0 & 9.7 & 9.7 & 8.8 & 8.1 & 6.7 & 6.2 & 6.0 & 5.5 \\
\hline NZ & 5.1 & 4.9 & 5.3 & 5.9 & 6.8 & 7.4 & 7.4 & 7.3 & 6.4 & 7.7 & 6.0 & 5.9 & 6.6 & 7.6 & 7.5 & 6.5 & 5.5 & 5.6 & 4.2 \\
\hline UK & 3.6 & 3.2 & 3.9 & 4.6 & 3.7 & 3.5 & 3.6 & 2.9 & 5.3 & 4.3 & 3.4 & 4.2 & 4.7 & 6.9 & 4.3 & 3.6 & 5.0 & 4.2 & 4.2 \\
\hline Taiwan & 3.6 & 4.3 & 4.4 & 4.4 & 4.4 & 4.6 & 4.5 & 4.8 & 4.8 & 4.8 & 5.0 & 4.4 & 4.0 & 3.5 & 3.5 & 4.0 & 3.8 & 3.5 & 3.8 \\
\hline Singapore & 4.6 & 5.5 & 6.5 & 5.2 & 5.3 & 5.4 & 4.1 & 4.6 & 3.7 & 4.7 & 5.3 & 4.4 & 4.2 & 3.3 & 2.8 & 2.8 & 2.8 & 2.4 & 2.8 \\
\hline Thailand & 1.2 & 1.3 & 1.8 & 2.0 & 2.1 & 2.4 & 2.2 & 2.0 & 1.4 & 1.7 & 1.8 & 1.9 & 2.1 & 2.1 & 2.6 & 3.0 & 2.6 & 2.6 & 2.4 \\
\hline ROW & 33.9 & 32.8 & 33.0 & 32.8 & 32.9 & 32.7 & 35.4 & 36.5 & 35.7 & 34.2 & 33.5 & 34.2 & 32.7 & 30.8 & 30.7 & 28.5 & 29.0 & 29.0 & 25.5 \\
\hline Total (\$b) & 47.2 & 53.7 & 58.3 & 62.7 & 64.7 & 71.6 & 76.9 & 84.7 & 88.9 & 86.8 & 110.3 & 122.5 & 119.4 & 107.9 & 117.7 & 139.0 & 163.7 & 168.3 & 223.1 \\
\hline
\end{tabular}

Source: ABS Cat. No. 5368.0 Tables 14a) and 14b) 
Table 3 Australia's Merchandise Imports, by Trading Partner (per cent)

\begin{tabular}{|c|c|c|c|c|c|c|c|c|c|c|c|c|c|c|c|c|c|c|c|}
\hline & 1990 & 1991 & 1992 & 1993 & 1994 & 1995 & 1996 & 1997 & 1998 & 1999 & 2000 & 2001 & 2002 & 2003 & 2004 & 2005 & 2006 & 2007 & 2008 \\
\hline China & 2.7 & 3.5 & 4.2 & 4.7 & 5.0 & 5.0 & 5.3 & 5.7 & 6.0 & 6.5 & 7.8 & 8.8 & 10.1 & 11.0 & 12.7 & 13.7 & 14.5 & 15.4 & 15.6 \\
\hline USA & 23.5 & 24.0 & 22.3 & 21.2 & 21.8 & 21.6 & 23.0 & 21.8 & 22.3 & 20.8 & 19.8 & 18.2 & 18.1 & 15.8 & 14.5 & 13.7 & 14.0 & 12.6 & 11.8 \\
\hline Japan & 18.8 & 17.6 & 18.1 & 19.1 & 17.8 & 15.5 & 13.0 & 13.7 & 13.8 & 13.4 & 13.1 & 13.0 & 12.3 & 12.5 & 11.8 & 11.0 & 9.8 & 9.6 & 9.0 \\
\hline Singapore & 2.5 & 2.7 & 2.4 & 2.6 & 3.0 & 3.2 & 3.4 & 3.0 & 2.8 & 4.1 & 3.2 & 3.4 & 3.4 & 3.4 & 4.4 & 5.5 & 6.1 & 5.6 & 7.2 \\
\hline Germany & 6.4 & 6.1 & 5.8 & 5.8 & 6.0 & 6.7 & 6.0 & 5.6 & 6.0 & 5.7 & 5.0 & 5.7 & 5.7 & 6.2 & 5.8 & 5.6 & 5.1 & 5.2 & 5.0 \\
\hline Thailand & 1.0 & 1.2 & 1.3 & 1.2 & 1.3 & 1.3 & 1.4 & 1.6 & 1.7 & 2.2 & 2.4 & 2.3 & 2.5 & 2.8 & 2.7 & 3.1 & 3.6 & 4.2 & 4.5 \\
\hline UK & 7.0 & 6.2 & 5.9 & 5.7 & 6.0 & 6.0 & 6.4 & 6.4 & 6.0 & 5.3 & 6.0 & 5.3 & 4.6 & 4.2 & 4.1 & 4.0 & 3.6 & 4.3 & 4.4 \\
\hline Malaysia & 1.4 & 1.6 & 1.7 & 1.7 & 1.8 & 2.0 & 2.2 & 2.5 & 2.8 & 3.2 & 3.7 & 3.3 & 3.1 & 3.3 & 3.9 & 3.9 & 3.8 & 3.9 & 4.0 \\
\hline NZ & 4.4 & 4.6 & 4.6 & 4.9 & 5.0 & 4.7 & 4.7 & 4.4 & 4.0 & 4.0 & 3.8 & 4.0 & 3.8 & 3.9 & 3.7 & 3.5 & 3.1 & 3.3 & 3.4 \\
\hline ROK & 2.4 & 2.5 & 2.7 & 3.0 & 2.6 & 2.9 & 3.0 & 3.6 & 4.3 & 3.8 & 4.1 & 3.9 & 3.7 & 3.6 & 3.5 & 3.3 & 3.9 & 3.2 & 2.9 \\
\hline ROW & 30.0 & 30.0 & 30.9 & 30.3 & 29.8 & 31.1 & 31.7 & 31.7 & 30.4 & 30.8 & 31.2 & 32.2 & 32.7 & 33.3 & 32.9 & 32.6 & 32.6 & 32.7 & 32.3 \\
\hline Total (\$b) & 37.1 & 49.6 & 55.5 & 62.3 & 68.0 & 77.4 & 78.3 & 83.3 & 96.7 & 101.5 & 116.9 & 117.7 & 127.6 & 129.9 & 141.2 & 155.7 & 176.0 & 187.8 & 225.8 \\
\hline
\end{tabular}

Source: ABS Cat. No. 5368.0 Tables 14a) and 14b). 
Table 4: Chinese Investment in Australia by industry, as approved by the Foreign Investment Review Board (FIRB) 1992-2007

\begin{tabular}{|c|c|c|c|c|c|c|c|}
\hline Year & Number & $\begin{array}{l}\text { Agriculture, } \\
\text { forestry and } \\
\text { fisheries } \\
\text { (\$A } \\
\text { million) }\end{array}$ & $\begin{array}{l}\text { Manu- } \\
\text { facturing }\end{array}$ & $\begin{array}{l}\text { Mineral } \\
\text { exploration } \\
\text { and } \\
\text { resource } \\
\text { processing }\end{array}$ & $\begin{array}{l}\text { Real } \\
\text { estate }\end{array}$ & $\begin{array}{c}\text { Services } \\
\text { and } \\
\text { tourism }\end{array}$ & Total \\
\hline 1993-94 & 0 & 0 & 0 & 0 & 0 & 0 & 0 \\
\hline 1994-95 & 927 & 0 & 1 & 42 & 426 & 52 & 522 \\
\hline 1995-96 & 267 & 0 & 6 & 52 & 137 & 31 & 225 \\
\hline 1996-97 & 102 & 10 & 3 & 5 & 176 & 17 & 210 \\
\hline 1997-98 & 0 & 0 & 0 & 0 & 0 & 0 & 0 \\
\hline 1998-99 & 0 & 0 & 0 & 0 & 0 & 0 & 0 \\
\hline 1999-00 & 259 & 35 & 5 & 450 & 212 & 10 & 720 \\
\hline 2000-01 & 0 & 0 & 0 & 0 & 0 & 0 & 0 \\
\hline 2001-02 & 237 & 0 & 47 & 20 & 234 & 10 & 311 \\
\hline 2002-03 & 0 & 0 & 0 & 0 & 0 & 0 & 0 \\
\hline 2003-04 & 170 & 0 & 2 & 971 & 121 & 5 & 1,100 \\
\hline 2004-05 & 206 & 2 & 0 & 39 & 181 & 42 & 264 \\
\hline 2005-06 & 437 & 0 & 223 & 6,758 & 279 & 0 & 7,259 \\
\hline 2006-07 & 874 & 15 & 700 & 1,203 & 712 & 11 & 2,640 \\
\hline
\end{tabular}

Source: Australian Treasury, Foreign Investment Review Board, Annual Report, various years.

Foreign Investment Review Board (FIRB)-approved Chinese FDI amounted to almost \$A10 billion in 2005-06 and 2006-07, of which about \$A8 billion or 80 per cent was in minerals and resources. The Australian Treasurer reported in his speech of 4 July that, since November 2007, however, he had received applications to the value of \$A30 billion for investment projects from China (AFR, 2008, 5 July). Should these investments have materialised, the increment to Chinese FDI would represent a large jump in China's foreign investment presence in Australia, but it would still leave China a much less important investor than United States or the United Kingdom, both of which now have less sizeable trade relationships with Australia than does China. The data for the fiscal year to 2008 have not yet been published (as of June 2009). Foreign investment approvals through FIRB are commonly higher than investments actually realised as measured by the Australian Bureau of Statistics (ABS). But approved 
foreign investment inflows into Australia (according to the FIRB) rose by 82 per cent in 2006-07, compared to the previous year, with inflows increasing from \$A85.6 billion to \$A156.4 billion. The United States was the largest source of investment (\$A45 billion) or 29 per cent of the total; next was Singapore (\$A18 billion), Mexico (\$A16.8 billion) and The Netherlands (\$A12.8 billion). From this perspective, a jump of \$A30 billion in investment from China would hardly be out of proportion.

As measured by the Australian Bureau of Statistics (ABS), Chinese investment inflow into Australia averaged only \$A180 million annually over the past decade. By 2008, the accumulated stock of Chinese investment in Australia stood at \$A7.9 billion (more than twice the level of two years earlier and on par with that of Taiwan. Of that total, ABS reports that \$A3.1billion is direct investment (the balance being portfolio flows). As of 2008, China’s FDI in Australia represented less than one per cent of the total stock of FDI in Australia (\$A392.9billion). Its concentration in the resources sector gives China a higher share of resource investments in that sector but it still holds a relatively small share in that sector too (in 2007, the stock of direct investment in the minerals sector in Australia was about \$A90billion).

Investment in the resource sector by Chinese enterprises has remained active through the global financial crisis (arguably it has become even more so) as bank finance and other investors have retreated from the market. A review of significant activities in the last 12 months shows a range of strategies that might be expected in the resource sector

- Some propose to take ownership of particular projects, such as the agreement by Xinwen Mining to pay A $\$ 1.5$ billion for Linc Energy’s Bowen Basin coal tenements in Queensland in September 2008 (although as of the time of writing in 2009, the deal had yet to be completed)

- $\quad$ some establish the right to explore such as Shenhua Energy's reported payment for a_licence to explore coal deposits at Liverpool Plains in NSW in October 2008

- $\quad$ some take a majority share in the company, such as China Nonferrous Metal Mining Group’s agreement to take a majority stake in Australian rare earths miner, Lynas Corp Ltd in May 2009 
- others take up minority positions such as Hunan Valin Iron and Steel Group’s purchase of 16.5 per cent in Fortescue Metals Group in February 2009, or the proposal by Ansteel to increase its minority shareholding in Gindalbie Metals (May 2009).

These are transparent transactions, unlike many Japanese investments which are joint ventures.

Three cases of Chinese investment in the Australian resource sector have attracted particular policy attention. They are

- Chinalco’s investment in Rio Tinto;

- Sinosteel's takeover of Midwest and its bid for Murchison;

- Minmetals purchase of OZ Minerals.

These are discussed in more detail in Box 1. The commentary on these projects focused on their effect on competition, their impact on cooperation between Australian companies and their im[;ications for security issues. In all cases, the matters could have been resolved within the existing regulatory structures and in all cases the strategy of Chinese investors appeared consistent with corporate commercial interests.

Box 1: Three Case Studies

In February 2008, BHP Billiton had announced a hostile bid to take over Rio Tinto. Chinalco and Alcoa also bought 9 per cent of Rio Tinto at that time. By the end of 2008, BHP had withdrawn its bid and then in February 2009 Chinalco proposed to extend its ownership to 18 percent in order, it was reported, to provide funds to help refinance Rio Tinto debt accumulated in its purchase of Alcan. The purchase was consistent with Chinalco's announced international strategy to that time, and also provided access to Rio's assets of hydro-powered aluminium smelters, acquired from Alcan.

The Chinalco proposals raised issues about foreign investment by a government-owned firm, about the impact of the proposal on competition and, in the case of the 2009 offer, about the extent of control which the ownership share implied. Commercial criteria decided the matter when in June 2009 Rio Tinto management withdrew from the 
arrangement with Chinalco, but not before extensive regulatory review, which has left a higher residual of uncertainty around investment from China.

The February 2008 purchase had triggered the attention of the Foreign Investment Review Board (FIRB) under the new guidelines for FDI by state owned enterprises which we discuss in the body of the paper. On Chinalco's investment, the Treasurer, Wayne Swan, said the Australian government needed assurance that investment proposals from state-owned enterprises and sovereign funds were commercial, and did not intend to advance strategic or even political objectives. In July Mr Swan added that the Government would 'more carefully consider proposals by consumers to control existing producing firms'. The Treasurer pointed out that this would be especially a concern if the resource was big and already developed and if the proposed buyer was moving to 'a point of control over pricing and production'. ${ }^{5}$ On 24 August 2008, the Treasurer approved investment by Chinalco up to 11 per cent of the Rio Tinto Group (or 14.99 percent of Rio Tinto Plc, the arm of the Rio Tinto Group which was listed on the London Stock Exchange). The Treasurer also imposed a number of undertakings on Chinalco including those not to raise its shareholding any further without fresh approval and not seeking to appoint a director as long as its shareholding is less than 15 per cent. FIRB returned to give attention to Chinalco in 2009 after the new proposal, and the Board, soon after the bid, announced it would require an extended period to mid June to review the proposal. The Rio management withdrew from the arrangement before this date.

The second set of issues related to the capacity of Chinalco to affect the iron ore price paid by Chinese steel mills. The Australian Consumer and Competition Commission (ACCC) in March 2009 released its opinion that the takeover would not lessen competition in any relevant market (ACCC, 2009). The ACCC explained that any attempt to lower the world price through increased production (assuming Chinalco had the ability to drive such investment), so as to benefit consumers such as Chinese steelmakers, would lead to drops in output by other suppliers which would then cause world prices to rise again, or else Rio would have to bring on project after project to

| ${ }^{5}$ Malcolm Maiden, 'Canberra and share rally remake Rio game for Chinalco', The Age, 5 May 2009 
keep the price down. The price drop could not be sustained. The ACCC also noted that this strategy required a 'China Inc' view of the world.

In addition to the Treasurer's approval, Rio Tinto's shareholders needed to agree to the \$US19.5 billion investment which would double Chinalco’s equity stake in Rio Tinto. There were reports of shareholder resistance and, given the improved outlook for resource markets, in June 2009 Rio announced that the proposal would not proceed. Rio had to pay a break fee to Chinalco. At the same time, Rio entered into a joint venture with BHPB to raise funds from merging their Western Australian iron ore businesses.

Another case of interest was Sinosteel's takeover of Midwest Corporation in 2008. This was the first hostile takeover by Chinese investors. Previously, Murchison Metals, a neighbour of Midwest, had been bidding for Midwest. If Midwest and Murchison had merged before Sinosteel's acquisition of Midwest, Sinosteel, even though already a shareholder, would have had less control over the projects. Sinosteel then held up the Murchison deal and itself took over Midwest, for which the Treasurer provided approval in December of 2007. With full ownership of Midwest Sinosteel could secure an off-take agreement for its output, which would otherwise have had to be negotiated. Having bought Midwest, it then paid to manage the merger with Murchison, which it now appears to be planning to purchase. The Treasurer has so far approved Sinosteel ownership of Murchison up to 49/9 per cent (Sinosteel had applied for 100 per cent but had withdrawn that application). Both Midwest and Murchison mine the same pair of deposits and there are advantages in a merger, including the cost savings from exploitation of the neighbouring deposits, stockpile efficiencies, better sequencing of the development, coordinated exploration and the advantages of blending the ores of different qualities plus a greater capacity to raise funds. Also the Western Australian government has chosen a Murchison infrastructure proposal for a port and rail link to the Mid West area of WA.On February 16 2009, OZ Minerals reported that Chinese trading group Minmetals had made a bid for OZ Minerals which had been working on options to repay debt. The FIRB process was more important than in the Midwest case. The OZ Minerals directors had recommended the proposal but on March 27, 2009, the Australian Treasurer rejected Minmetals' bid based on national security concerns regarding the flagship Prominent Hill mine's location in the defence-sensitive Woomera, being too close to the defence facility Prohibited Area weapons testing 
range. On April 1, 2009, Minmetals revised its bid. The revised offer excluded the Prominent Hill mine and other 'sensitive' assets although it was about US\$500 million short of the original proposal. It was approved by the Treasurer on 23 April 2009. The miner's bankers had agreed to an extension of the refinancing deadline to June 30 to allow the Minmetals transaction to proceed.

\section{Capturing the gains from FDI}

Foreign direct investor participation in the economy generates a range of benefits including higher incomes, productivity and competitiveness through providing new technology, know-how, marketing, access to lower cost capital as well as opportunity for shifting risks. The principal benefits that are likely to be brought by Chinese foreign investor participation in Australian resource projects at this time is that they might bring additional capital and links to rapidly growing markets. At the same time, there are issues to be managed and resolved in capturing the full benefit from foreign investment.

Here attention is focused on FDI in the resource sector. There is a rich literature on foreign investment in other industries which deals with a range of general issues (Drysdale (1972); Caves (1978); Dosi, Pavitt and Soete (1990); Borensztein et al. (1998); Hanson (2001); Barro and Sala-i-Martin (2004); Dunning and Lundan, (2008)).

In the minerals sector, because of its capital-intensive nature and its geographical remoteness, benefits tend to be concentrated on returns to government associated with national ownership of the resources and to sectors like engineering, financial and commercial services and transportation that are closely linked to mining. These characteristics are said to restrict the benefits from FDI in the resource sector in developing countries because of weaknesses in taxation systems and because of the limited linkages between the resource sector and other sectors in those economies (UNCTAD, 2007 p. 140 and p.168). There are higher levels of local procurement in developed, resource-rich host economies which are the home base for the globalising mining supply businesses that rank among the largest and most profitable companies in the world (UNCTAD, 2007, Box IV.3). Australia counts itself in this latter category. 
The pervasive impact of the mining sector activity, despite its heavy concentration geographically in Western Australia and Queensland, can be seen in its effect on incomes, employment, and the key macro-economic indicators right across the Australian economy (Treasury, 2008, pp.16-20).

\section{The scope of benefits in the resource sector}

FDI in the resource sector offers a number of advantages to the host country including the provision of capital, technology, know-how and access to markets. These benefits are substantial given the scale, technological complexity and long project lives that typify resources investments in Australia.

In addition, FDI is often part of an integrated set of mining and industrial activities. UNCTAD (2007, p. 111) identifies an overall trend of increasing integration between mining and smelting particularly in aluminium but also in iron ore. These linkages provide a basis for the marketing and distribution of the output of mineral projects. Risks are shared along the production chain. This is an additional benefit of FDI in the development of large scale resource projects.

Vertical integration is not the only way to manage project risks. Other options include the use of long term contracts between independent firms, complemented by portfolio capital flows. Smith (1980) explains the rationale for the combination of long term contracts in association with arrangements for setting prices. They serve as a means of maximising the value of projects and achieving an efficient distribution of risks. The contracts also allow the mining company to raise finance for large projects which in mining have long lead times and produce outputs with specific characteristics. Buyers then have to commit investments in complementary processing methods or at least face some costs in adjusting their operations to outputs from different sources. As Smith explains, the result is that buyers and sellers in these markets operate portfolios of bilateral trade or sales and procurement links.

Provision of equity capital to the project or the mining company by the buyers of the output demonstrates another form of commitment by them. Control is not required, but may be sought depending on the nature of the project, though even an investment to a 
level which is less than required for control may still meet the definition of FDI. If that investment by the buyer also reduces the cost of finance to the mining company (by allowing that company to ease what otherwise would be restrictions on its capacity to raise debt) then it adds to the surplus available for distribution.

These circumstances are those which are likely to dominate Chinese investment interest in the Australian resource sector. Chinese investors are overwhelming likely to want a stake in projects that provides a link to markets in China and offers an additional source of capital, and to want to invest in partnership with Australian or other foreign firms that bring management know-how and technology as well as capital to mining projects.

\section{Managing the issues with resource sector FDI}

Significantly the main host country benefits from resource project development accrue via income flows, including to governments. There are issues related to the presence of foreign capital in resource sector projects, including with the management of the income flow from them. Resource projects are associated with the presence of variable rents. They involve the development of resources which are not replaceable and the global stock of which has scarcity value both because of its size and its uneven distribution geographically. The value of the resource in this circumstance, at least for infra-marginal projects, enjoys a premium or rent over the cost of extraction. UNCTAD (2007, Box VI.3) lays out some options for capturing these rents, including taxes based on revenue, output and profit. There are trade-offs between the costs of collection and administration of these taxes and their effects on economic efficiency.

Figure 1 shows the breakdown of payments to governments at all levels in Australia (other than for services) by minerals companies. These data exclude income taxes paid by non-resident management and employees. The chart reveals that output-based taxes and licensing fees paid to state governments are a relatively small proportion of the total tax take compared to taxes on income. Income taxes have an effect on the incentive to invest compared to taxes on pure profit (Garnaut and Clunies Ross, 1975; Garnaut and Clunies Ross, 1983) while output taxes affect the incentives to exploit a deposit. The composition of the doughnut in Figure 1 suggests the tax allocation in the 
Australian resources sector is skewed towards the collection of revenues from resource firms via income taxation

Figure 1: Taxation Payments to Governments, 2006/07, \$m

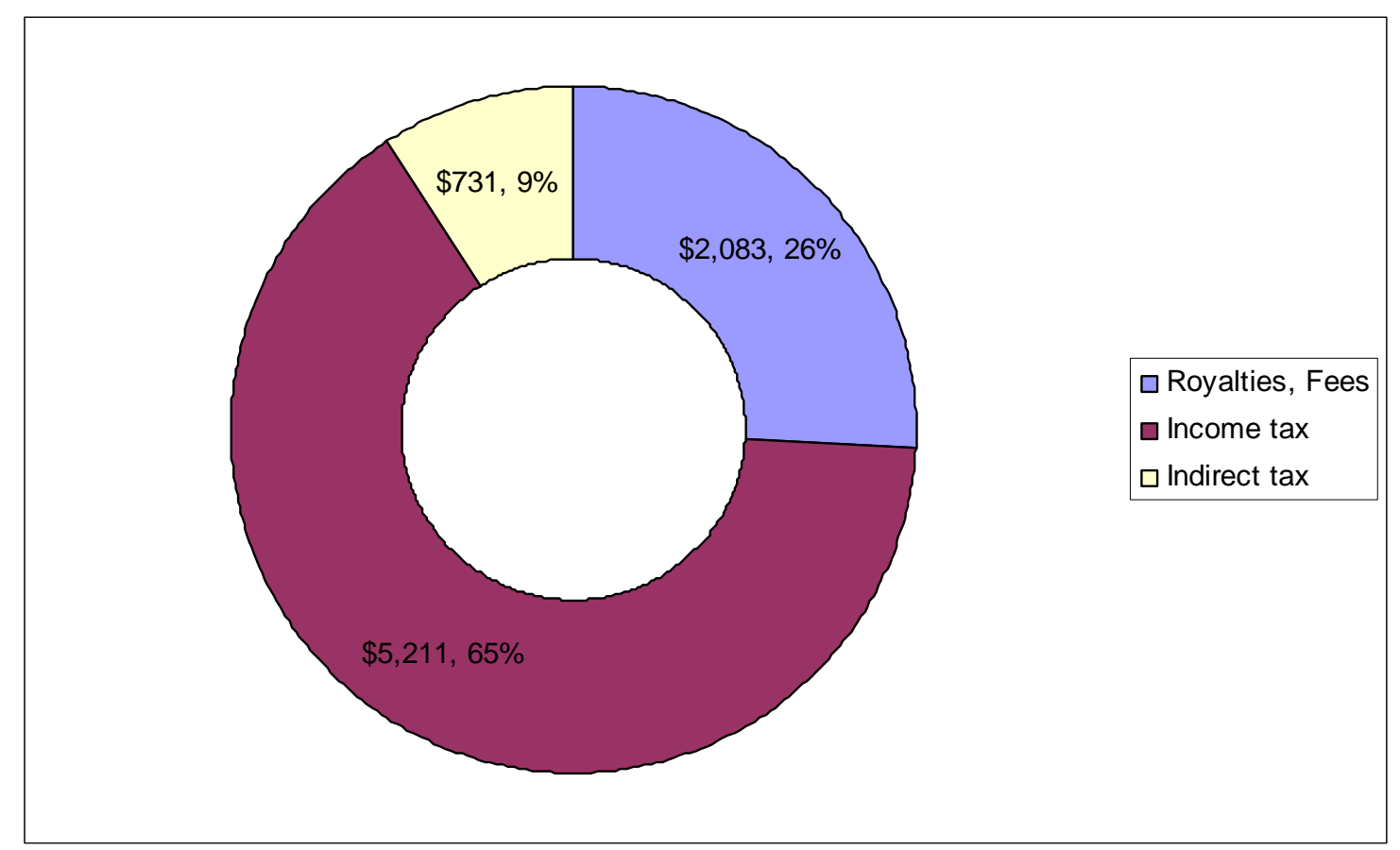

Source: http://www.minerals.org.au/information_centre/minerals_industry_survey_report/publications2

Inefficient taxation regimes run the risk of collapse as circumstances change. The minerals and energy sector tax regime in Australia is complicated by the Australian federal system and the evolution of the distribution of taxation powers between the Commonwealth and the States but it is legislatively and politically robust. In federal jurisdictions, such as those that cover the offshore production of oil and gas, a variant of a resource profits tax regime applies, although the primary form of non-income taxation of on-shore projects is through state-levied royalties.

The profitability of long-lived resource projects can change over time, creating incentives to change the fiscal arrangements where political and legislative systems are not robust, especially in periods in which there is a substantial increase in the rent value of resources occasioned by sharp rises in the terms upon which they are traded, such as 
has been the experience in recent years (Duncan, 2006). UNCTAD (2007) notes that many studies find that taxation regimes in minerals projects are regressive. It discusses (Box VI.5) options for more progressive regimes of the kind that are in part in place already in Australia.

In an advanced economy, the perception of an unfair and inefficient distribution of rents in projects may emerge, especially in the context of rising prices. This may not be an issue in the management of existing projects but could hinder new projects which might operate on the same terms as existing projects. Chinese investment in Australian minerals is a consequence of the growth in demand in China. That growth in demand has contributed to rising prices in the same way that, in the 1960s and 1970s, the growth of Japanese demand saw a similar rise in Australia and global commodity prices. As investment arrives in host countries like Australia to take advantage of new profit opportunities in resource production and trade, the distribution of rents becomes an issue in policy debate. There may be scope to gain from the implementation of more efficient taxation regimes. Hogan (2007) argues for the translation of arrangements for oil and gas in Australia to onshore minerals but the established taxation arrangements for onshore minerals are the product of a long and complex history of fiscal relations between the Commonwealth and the States and are unlikely to change soon, even in the context of the current federal taxation and fiscal arrangements reviews. As Hogan (pp.100-101) concludes:

Significant information on the net cash flow of resource projects is required to administer the petroleum resource rent tax. Extending a profit based royalty such as the petroleum resource rent tax to onshore mineral resources would involve significant transitional costs and increase the information requirements for administering resource taxation arrangements in Australia. There are also likely to be a number of issues that would need to be resolved in replacing the current systems that apply across several jurisdictions with a consistent mineral resource rent tax — for example, the taxation treatment of failed exploration projects would need to be considered (companywide deductibility of exploration expenditures is an important component of the petroleum resource rent tax). 
There is another issue to do with taxation that arises in resource projects that are owned and controlled by the buyers of output from the project as part of an internationally integrated operation. This is the familiar issue of the opportunity for transfer pricing when there are not arms-length transactions between firms. The importance of transfer pricing lies, of course, in its potential to reduce the taxation take of the host country through understatement of resource project profits.

The aluminium industry in which international vertical integration is pervasive, significantly because of the importance of the specific technical characteristics of inputs across a production chain, was traditionally the industry in which transfer pricing potentially presented the most important challenge to Australian taxation authorities. In such cases, the taxation authorities can declare the appropriate price of output in determination of tax obligations, even when there is no readily observable arms-length price of output. These are circumstances which require active taxation authority attention. Where participation in ownership does not involve control (a minority equity holding or partnership without control) the question does not arise.

A second major set of issues concerns the local and global environmental effects of resource sector projects. This concern applies to some extent to all resource projects. If projects add to environmental degradation, that is a consequence of a failure to bring home to investors the consequences of the project. In other words, it is the result of the failure of the host country to correct the market failure associated with the environmental externality and not related to the presence of foreign investment as such.

Are there specific environmental issues associated with projects which involve foreign investment? Do investors in resource projects seek a haven from their domestic regulatory environment or do they apply global standards? UNCTAD (2007, p. 147) reports that most large mining companies apply at least their home standards and that in many cases rigorous codes are also applied to subcontractors. Large and established multinationals have a better environmental performance particularly compared to smaller local companies. They 'introduce and diffuse higher standards and more advanced technologies for environmental protection' (p. 148). UNCTAD does note that some new entrants in resource sectors are based in countries with relatively weak 
environmental legislation which involves a risk, but it concludes that environmental performance depends on 'host-country regulations and the capacity to implement them' (p. 148).

A third set of issues concerns the social impacts of projects. In Australia, most mining investments are in remote locations and the principal social impact is upon indigenous communities. Although it was not the case in the past, the framework for settlement of mineral leasing rights is now subject to more robust arrangements and public scrutiny. International and domestic mining companies are also at the forefront of the development of indigenous employment programs. While there are other social and environmental issues in more populous parts of the country that arise in the development of minerals and resource projects (such as was the case in the Hunter Valley or is currently the case in the Liverpool Plains around BHP Billiton's coal development), they are not distinctively associated with foreign investment projects.

In brief, we have identified a number of issues that are sometimes raised about the impact of FDI in a host economy, including those associated with the management of income flows and with the environmental and social impacts of projects. In all cases, these problems arise not from the presence of foreign investment as such but because of inefficient policy in the host economy. Capital flows run the risk of reducing welfare if there are domestic distortions or weaknesses in the regulatory or policy framework. If these policy distortions or weaknesses are evident and important, the solution is a domestic reform program, rather than restriction on the inflow of foreign capital.

\section{Is Chinese FDI in the resource sector different?}

Investment flows in the resource sector can take the form of FDI or portfolio flows either as an independent investment or as part of a package of risk management tools. The motivations for FDI have been discussed in some detail above and extensively in the literature (Dunning and Lundan, 2008). The gains from investments via FDI provide a return on assets which are specific to the investing firm and for which participation in production (rather than licensing) is an efficient method of earning that return. 
Portfolio flows are not necessarily associated with these firm-specific assets, do not involve management of the assets in which equity is acquired, and do not involve control over the operations of firms or other entities in which equity is held except through the effect of entry or exit from ownership of those assets on their price. In principle, therefore, there is every reason why the interest of portfolio investors in the mining sector and other sectors of the Australian economy should be welcomed. It adds to the stock of capital to which the country has access for investment in profitable resource sector and other activities.

There are good reasons for the buyers of natural resources also to be investors in projects as noted above. There are also reasons why buyers might wish to seek control in projects which, because of product characteristics, logistics or the lumpiness of the investments involved at both ends, are efficiently part of an integrated international production chain. As we have also noted above, this has been a characteristic of efficient investment in the resource sector for many years, including in cases in which end-users of the product are controlling investors in projects that are integrated into international operations. So it is a new development in policy for the Treasurer to make it explicit that projects in which there is participation in ownership of projects 'to the point of control' by resource buyers will be routinely subject to more intense scrutiny (see the earlier quotation). This step increases the restrictiveness of access to the resources sector by foreign participants. The circumstances under which it might be justified need to be examined very carefully since it makes Australia potentially a less attractive location for investment and source of supply for a range of resource products for which this condition has not previously applied.

Another concern that is sometimes expressed is that Chinese investors might use their influence to lower prices of iron ore, so as to benefit the Chinese steelmakers. This requires a 'China Inc' view of the world, as the ACCC (2009) explained in its review of the Chinalco deal discussed above (see Box 2).

\section{The question of government ownership}

In the case of Chinese FDI, there is the additional question of whether government or state-ownership should matter in the treatment of applications to invest. Chinese FDI is 
not the only FDI in which government ownership may be important. But growth in the number of projects in which interest is being expressed by Chinese entities with some measure of government ownership has been a factor in attracting policy attention. This includes both state-owned enterprises (SOEs) and sovereign wealth funds (SWFs).

The Australian government has responded with an elaboration of policy on screening foreign investments. In February 2008 it announced a set of guidelines which are reproduced in Appendix 1. These are the guidelines which are being applied in consideration of the Chinese and other FDI proposals that were discussed earlier and they include reference to whether:

1. An investor's operations are independent from the relevant foreign government.

2. An investor is subject to and adheres to the law and observes common standards of business behaviour.

3. An investment may hinder competition or lead to undue concentration or control in the industry or sectors concerned.

4. An investment may impact on Australian Government revenue or other policies.

5. An investment may impact on Australia's national security.

6. An investment may impact on the operations and directions of an Australian business, as well as its contribution to the Australian economy and broader community.

The guidelines assert that 'proposed investments by foreign governments and their agencies (for example, state-owned enterprises and sovereign wealth funds (SWF)) are assessed on the same basis as private sector proposals. National interest implications are determined on a case-by-case basis’ (Appendix 1). However, the guidelines go on to state that 'the fact that investors are owned or controlled by a foreign government raises additional factors that must also be examined' (Appendix 1) in the administration of foreign investment controls. This, it is argued, reflects 'the fact that investors with links to foreign governments may not operate solely in accordance with normal commercial considerations and may instead pursue broader political or strategic objectives that could be contrary to Australia's national interest' (Appendix 1).

This argument creates uncertainty about foreign investment policy towards Chinese investment and is inconsistent because it includes a dimension that is 'additional' to the test of 'national interest'. This additional test, we demonstrate below, is unnecessary. 
The 'national interest' test has, in the past, been an adequate yardstick whereby to manage the participation of FDI in the resources and other sectors of the economy. The additional tests on government-owned entities appear to discriminate against Chinese FDI proposals, since so many of them involve government-owned entities. There are other foreign investment policy regimes, for example in Canada ${ }^{6}$, that incorporate provisions about state-owned firms, but it is not clear that these provisions make sense for Australia.

\section{Additional scrutiny of government ownership}

The nature of the 'additional factors' that could demand a test of suitability beyond the 'national interest' test is difficult to imagine. There are three main possibilities.

1. FDI investments involving state ownership and dominant shareholding and control might be used to serve as a vehicle for shifting profits back to the home country through underpricing exports. Only if a) the government-owned firm is the buyer of the resource or is directly compensated by the home state for losses incurred and b) the government-owned firm dominates the host country market, preventing the host country taxation authorities from declaring the value of output against benchmark competitive prices might this be a problem. In these circumstances, there is a clear 'national interest' case for restricting foreign investment on monopoly grounds. It is not necessary to identify any 'additional factors' flowing from state ownership in order to reach this conclusion.

2. FDI investments involving state ownership and dominant shareholding and control might be used to serve as an instrument for subsidising the development of 'excess capacity' or 'extra-marginal' projects and ratcheting resource prices down. Only if the government-owned firm totally has market power in the particular resource market concerned might this be a problem and in this circumstance there is a clear case for restricting foreign investment on 'national interest' grounds and, again, identification of 'additional factors' associated with state ownership is not necessary. The recent determination by the ACCC in respect of Chinalco's offer for an increased share in Rio Tinto demonstrates that Australia has both the policy regime and institutions necessary to deal rationally and comprehensively with issues of this kind. The governments of resource

\footnotetext{
${ }^{6}$ See the Canadian guidelines at: http://www.ic.gc.ca/epic/site/ica-lic.nsf/en/lk00064e.html\#state-owned
} 
deficient countries may provide, and have in the past provided, capital subsidies to resource or energy developments by private investors or state investors for 'resource security' reasons in times of resource scarcity and tight markets. Acquiring a dominant position through a particular government-owned firm is likely to be a very blunt and ineffective instrument for achieving that policy objective. The evidence from the history of Japanese policies that extended subsidies to resource developers is littered with projects that did not survive a long term market test.

3. FDI investments involving state ownership and dominant shareholding and control might be used to pursue political or strategic goals inconsistent with the efficient development and marketing of national resources. In such cases again, clearly 'national interest' dominates all other considerations. In a case in which a strategic resource, say a uranium project which had dominant supply status, was either a trade or the foreign investment target, political and security issues need to be dealt with in a state-to-state framework. In less strategic contexts, all firms that invest abroad, private as well as public, are ultimately subject to the laws and policies of the countries in which they are incorporated (at home and in the countries in which their subsidiaries operate) and questions of extraterritoriality do arise in the operation of firms internationally and have to be covered by state-to-state dealings.

In all of these cases, a 'national interest' test is adequate to handle the issue, whether the foreign investment is government-owned or privately owned. Note that these issues do not arise at all for any foreign investment in which there is minority participation without control, by either a government-owned or privately owned firm ${ }^{7}$. The former cases are extreme and unusual. The latter cases are, as we have shown, by far the most common in which Chinese state-owned investments are involved in the Australian resource sector.

Some might argue that investment by a government-owned enterprise is likely, of its nature, to be inefficient and resource-wasting. Government-owned enterprises have

\footnotetext{
${ }^{7}$ A structure of minority holdings through joint venture, as discussed on p. 12 above, or the procurement of a position on a board may permit a measure of control that requires scrutiny in either privately-owned or government-owned or related investments.
} 
their origins in bureaucratic systems and have governance structures that are not subject finally to the disciplines of the market. Would Singtel, a Singapore government-owned telecommunications provider and investor in Optus, have qualified for scrutiny merely on that ground? Whatever the firm-specific advantage a government-owned foreign investor in the resource industry brings to a project (commonly it will be a marketing link involving integration of operations along a production chain or access to additional capital), the value it puts on the asset will be ultimately tested in the market. It has been the practice for an assessment of the managerial capacity of a foreign investor not to form part of the review process. That a foreign investor is government-owned hardly seems grounds for now departing from that very sensible practice.

In fact, the empirical evidence suggests that state-owned foreign investors have performed well (Young and Lu, 1998). Multinational state-owned enterprises from Eastern Europe perform similarly to other foreign firms. Nor is there any evidence of the use of state power or privileged information in their business abroad. The goals of these ventures appear to be simply to operate successfully within the confines of the market. Our case studies also demonstrate the consistency of investment strategy with commercial motivation by Chinese investors.

\section{Market disciplines on Chinese firms}

The a priori identification of a class of investment proposals as deserving of special scrutiny introduces an element of pre-judgment into the foreign investment review process, departing from the well-established and respected case-by case approach. It is unfortunate that this is occurring at a time when, rather than being cautious about the participation of Chinese state-owned firms, it is strategically important that Australia, and other sophisticated market economies, welcome it. State-owned firms in China are increasingly subject to the disciplines of the market at home. They have preferred access to domestic credit through the state-owned banking system but on terms that are, given that distortion, increasingly commercially based ${ }^{8}$. The prevalence of state-owned firms is wider in China than was the prevalence of state-ownership, strictly defined, in the resource-consuming and resource investing industries in Japan thirty or forty years ago, but their entrenchment in the market is not so different. Chinese companies in

\footnotetext{
${ }^{8}$ Their access to funds from that source for foreign investment is constrained by commercial discipline, as recent experience with investment in the Indonesian power sector appears to attest.
} 
which the state has a stake are publicly listed at home and increasingly in Hong Kong and abroad. Corporate organisation and corporate governance in China is in a state of transition and is evolving towards a system increasingly governed by market institutions.

As Woetzel (2008) says:

An out-of-date impression of state-owned companies distorts the picture of China's competitive landscape and masks both opportunities and threats facing multinationals. A more current view would, for example, have them consider more favourably the value that certain state-owned companies might bring to a global partnership. A realistic multinational must also recognize that they will become more attractive to top talent and, probably, more innovative. Both developments will ratchet up the level of competition.

Thornton (2008), a director on the board of large Chinese state-owned firms, observes: ...officials at the highest levels (in China) recognize the need to put in place what might be called a modern system of corporate governance. They know that they'll be required to meet certain standards when they list their major companies in public markets in Hong Kong, London, or New York. They're also increasingly convinced that better corporate governance leads to better business results, greater efficiencies, wealth creation-all of those things that are good for companies, people, and the country. They have seen that even non-traded corporations like Saudi Arabia's Aramco have adopted leading corporategovernance practices.

\section{Australia's dynamic economic and political interests}

Australia's economic and grand political-strategic interests are in supporting the momentum towards market based corporate governance in China, and engaging with it. Practical engagement recommends welcoming investments from Chinese firms because through their fuller participation in the Australian market and other markets abroad they subject themselves to the disciplines of robust and well-governed market institutions. Unnecessary regulation of capital from this source into the Australian market will not only be detrimental to Australian economic interests by driving it to other markets, 
possibly less supportive of reform of corporate structures and corporate behaviour, but is likely to encourage a retreat to appeals to the power of the state in ways that are likely to be damaging to both our long term economic and political interests. The application of special conditions for these investments would reinforce the perception of the primacy of regulatory solutions over market solutions, and help sustain the dominance of the bureaucracy over the market in China.

\section{Sovereign wealth funds}

There is also the question of the potential role of China's sovereign wealth fund (SWF) in the Australian market for equity in the resource sector (Farrell, Lund and Sadan, 2008; Wood, 2007; J P Morgan, 2008; Monitor Group, 2008; Beck and Fidora, 2008; Zhang and He, 2008). Concerns about sovereign wealth funds have included the following ideas (Truman, 2008): that governments may mismanage the funds, including paying insufficient attention to corrupt practices; governments may manage the funds efficiently but for non-profit purposes (for example, direct them towards the protection of national champions, or promoting particular development strategies at home);SWF decisions may lead to 'financial turmoil'(as it was alleged of hedge funds); and foreign governments may have conflicts of interest with the managers of the assets in which they invest.

Wariness about sovereign wealth funds’ investment intentions appears unjustified. These funds seek diversified investment and higher returns in international equity investment like other portfolio investors, although they also have become more active in the mergers and acquisitions (M\&A) market. They add to the stock of capital for investment in this and other sectors and the capacity of the firms in which they invest to take advantage of the growth of trade and business opportunities. Should a SWF take a controlling stake in a particular enterprise, its investment can and should be subject to the same review and 'national interest' test as that of other investors. There is also a general interest in improving the standards of transparency and accountability on all SWFs, including our own, Futures Fund, which does not rank highly on these standards (Truman, 2008). 
The effect of policies directed selectively at Chinese state-owned investment is not confined to these investments. It is much broader. Australian decisions about FDI in which there is Chinese state ownership or about investments from a Chinese sovereign wealth fund cannot be prevented from influencing the views of other investors, including the managers of other SWFs, about the desirability of investing in Australia.

The scale of these funds is now significant and growing. Truman's (2008) data on Sovereign Wealth Funds around the world covers three such funds in China, which now ranks ninth in terms of offshore assets (with total assets of \$US272 billion of which \$US135 billion are invested offshore). The total value of SWFs, according to Truman's data, is over \$US5000 billion, of which nearly \$US3500 billion are international assets. Singapore has over \$US330 billion invested offshore.

Truman is concerned that the adoption of thoughtless protectionist policy towards a particular country's SWFs because of wariness about their investment behaviour is likely to be counter-productive. He suggests instead the international adoption of a blueprint of good practices that would refer to decision-making based on economic grounds alone, a commitment to good governance, a commitment to fair competition with privately owned investors and respect for host country rules.

Additional tests on this class of investment from China and decisions in each case are likely to make it more difficult to raise capital from others, such as from Japan. Uncertainties about rules on Chinese foreign ownership, such as caps on control, would impede capital flows more generally and raise the possibility that such caps might be applied more widely. At least some of the opportunities created by the growth in demand in China are likely to be lost. The current ambiguities are damaging to Australia's economic and long term political-strategy interests.

\section{Conclusions}

There is no persuasive case for any change in direction over control of foreign direct capital inflows in response the recent surge of interest of Chinese foreign direct investors in the Australian resources sector. Nor does the participation of the Chinese sovereign wealth funds in equity investments in Australia present any particular 
problem that cannot be dealt with appropriately within the policy framework that has been in place for some time. Chinese investors are under-invested in Australia, given the importance of China in Australia's trade, including and especially as a market for Australian resources, and given China's increased importance in global capital markets. Unless we deliberately constrain it to our own cost, China's share in Australian trade and in global trade and capital markets is destined to continue to grow and China's share in the direct and indirect ownership of Australian assets could easily grow commensurately.

Anxiety over the growth of foreign investment by China is as unfounded as it was, in earlier times, over the growth in foreign investment by Japan that accompanied the emergence of Japan as Australia’s major economic partner and a major supplier of capital to world markets.

Australia has a world class mining sector in which the largest and most competitive mining firms, both Australian and, to a very great extent, already foreign-owned, are heavily involved. The mining sector is deeply linked into and integrated with the rest of the Australian economy. The taxation and regulatory framework within which the mining sector is governed is well-established and robust. While some have suggested that the Australian taxation regime could be improved to ensure that the Australian public capture a higher share of the rents from high class mine investments or from unusual periods of high profit in the industry (Hogan 2007), the taxation regime is not a matter of active policy concern or public debate. If the efficiency of the taxation regime were a matter of public concern, we have argued, that is a matter that is needs to be addressed through reform of the taxation regime and its impact on both foreign and domestic firms, not a matter that is appropriately dealt with through controls or restrictions over FDI inflows. If there are environmental or social issues that require public policy intervention in the sector, they are issues that need to be dealt with through initiatives in environmental and social policy that impact on both domestic and foreign-owned operations, not through controls over foreign-owned companies alone. 
In brief, none of the usual and general arguments that might be advanced in caution about FDI participation in the sector apply in any substantial degree to the circumstances in Australia.

Increased uncertainty about the treatment of Chinese FDI in the resources sector is, at the margin, likely to damage the potential growth of the sector and Australia's full and effective participation in the benefits from Chinese economic growth through the growth of its market for industrial materials. An important objective is to assuage nascent Chinese corporate and policy strategies aimed at containing the growth of Australian market share. These strategies are familiar instruments in the pursuit of minerals and energy security by resource importers (Lesbirel, 2004). There is the added risk that application of 'additional' policy tests with respect to Chinese investment creates uncertainty and impediments to investment from other sources as well.

It may seem a puzzle as to how Australia got itself into this pickle over Chinese FDI. A few final words on that situation and what might be a sensible way out of it may be helpful.

The rapid rise of China caught many by surprise, although Australia has been on the leading edge of the wave. The intensification of Chinese investment activity in the Australian resource sector has also come swiftly although it had been gathering strength for some time. These developments alone do not explain the recent elevation of policy interest in Chinese investment in the Australian resource sector or the discomfit of the previous Australian government or the present government in dealing with the issue ${ }^{9}$. A series of events contributed, and they illustrate our argument as to the value of a generally applied national interest test to investments of this type. Two were of particular importance.

The first event was the high profile takeover bid by BHP Billiton for Rio Tinto (see Box 1) which opened up the question of Chinese investment in Australia. Whether it occurred to the architects of the BHP Billiton takeover strategy or not, a merger between the two largest international iron ore suppliers in the world was bound to

\footnotetext{
9 For early press comment on the policy issues and response see Matthew Stevens, 'China faces mining investment curbs,' The Australian, 26 June 2008 and Glenda Korporaal, 'China warns Labor on investment curbs’, The Australian, 2 July 2008.
} 
excite interest in China, the largest iron ore market in the world. Subsequently there was the bid by Chinalco for a higher stake in and a more comprehensive strategic alliance with Rio Tinto.

Chinalco, already a significant international investor in mining projects around the world moved to secure an initial minority stake in Rio Tinto in early 2008. Here is not the place to speculate about where this corporate activity will end but brief comment is in order on the implications of the development for framing policy towards FDI that incorporates state-ownership. As noted in Box 2, the Treasurer, after a recommendation by the FIRB, approved the investment by Chinalco of up to 14.99 per cent interest in the Rio Tinto Group. This share was less than the 'substantial interest' level of 15 per cent which applies under the FIRB policy ${ }^{10}$, and the Treasurer made the determination under the new guidelines applying to state-owned enterprises. Chinalco has moved to take a 'substantial interest' in Rio Tinto, so this new circumstance has to be considered by FIRB under Australia's foreign investment rules.

The second event was Sinosteel's investments in the mid west region of WA. It had applied to take over Midwest, a Western Australian iron ore company, which was approved in November just after the Rudd government assumed office. As explained in Box 2, Sinosteel also targeted Midwest's neighbour Murchison and it continues to wait for the FIRB ruling on its application. Sinosteel's interest in Murchison will have been increased by the recent WA government decision to ask a Murchison consortium to build a new port to serve the region. It has been suggested that a wholly Chinese-owned infrastructure network in the WA mid-west might be an obstacle in delivering iron ore to other markets. Again, this issue can be dealt with by the kind of conditions that the Western Australian government has routinely imposed on other infrastructure developments. The scale and structure of these investments do not suggest any considerations of 'national interest', effects on competition or strategic importance that might recommend their non-approval.

These and the other projects discussed in Box 2 have introduced some political confusion into the discussion of Australia's foreign investment regime over the past

\footnotetext{
${ }^{10}$ http://www.firb.gov.au/content/_downloads/General_Policy_Summary_April_2008.rtf See the earlier discussion (p.3) of the plasticity that has appeared in this test.
} 
year. Some of the confusion seems relate to uncertainty about how to respond to the growth of Chinese investment interest in the Australian resources and energy sector. The issues of state-ownership of investment, competitiveness in markets and political or security matters are issues that are not appropriately dealt with through additional restrictions and tests on Chinese or other foreign investment proposals. Uncertainty around these issues already runs the risk of hindering development of the industry's potential and damaging our longer term political and security interests. But much of the uncertainty has also been introduced by interested commercial and political parties in the play around the market (see Box 2).

The best way to dispel the uncertainty and confusion is through

a) re-assertion of the market framework within which all foreign investment proposals are examined in Australia and

b) initiation of government-to-government arrangements for routine consultation between Australian and Chinese authorities that would serve to facilitate scrutiny of competition, corporate governance, and financial transparency issues and have the practical effect of strengthening that framework over time.

The detail of the initiative we suggest here will need to be the subject of discussion and careful study elsewhere. 


\section{References}

Australian Bureau of Agricultural and Resource Economics (ABARE) 2007, Australian Commodities, Canberra, December.

ABARE, 2008, Australian Commodities, June Quarter 08.2, ABARE, Canberra, available from http://www.abare.gov.au/publications html/news/news/news.html\#

Albanese, Tom, 2008,'Winning Strategies for Global Champions', Speech to AustraliaIsrael Chamber of Commerce and Industry, 16 June.

Australian Bureau of Statistics (ABS), 2003, Foreign Ownership of Australian Exporters and Importers, 2002-03, 5496.0.55.00, ABS, Canberra.

ABS (Australian Bureau of Statistics), 2009, International Investment Position, Australia: Supplementary Statistics, 2008, 5352.0, ABS, Canberra.

Australian Competition and Consumer Commission (ACCC) 2009, 'Chinalco (Aluminium Corporation of China) - proposed acquisition of interests in Rio Tinto plc and Rio Tinto Lt', 25 March, available at http://www.accc.gov.au/content/index.phtml/itemId/501191

Australian Financial Review (AFR), 2008, 5 July;15 August.

Barro, Robert and Xavier Sala-i-Martin, 2004, Economic Growth, The MIT Press, Cambridge, Massachusetts.

Beck, Roland and Michael Fidora, 2008, 'The Impact of Sovereign Wealth Funds on Global Financial Markets’ ECB Occasional Paper No. 91, July, (available at SSRN: http://ssrn.com/abstract=1144482).

Borensztein, E., J. De Gregorio and J. W. Lee, 1998, 'How Does Foreign Direct Investment Affect Economic Growth?’ Journal of International Economics,1998, v45, (1 June), pp.115-135.

Brosio, Giorgio, 2006, 'The Assignment of Revenue from Natural Resources', Chapter 17 in Ehtisham Ahmad and Giorgio Brosio (eds), Handbook of Fiscal Federalism, Edward Elgar, pp.431-458.

Caves, Richard E., 1978, 'Policies Towards Trade in Raw Materials', Chapter 14 in Crawford, Okita et al (eds) Raw Materials in Pacific Economic Integration, Croom Helm, London, pp. 288-311.

Cook, Malcolm and Mark Thirwell, 2008, 'The Changing Global Financial Environment: Implications for Foreign Investment in Australia and China’ Lowy Institute Outcomes Report, Sydney, July.

Crawford, J. G., Saburo Okita, Peter Drysdale and Kiyoshi Kojima (eds), 1978, Raw Materials and Pacific Economic Integration, Croom Helm, London.

Davies, Ken, 2009, 'While global FDI falls, China’s outward FDI doubles', Columbia FDI Perspectives, No 5, 26 May, (http://www.vcc.columbia.edu/www.vcc.columbia.edu). 
Dosi, G., Pavitt, K. and Soete, L. 1990, The Economics of Technical Change and International Trade, Harvester-Wheatsheaf, New York.

Drysdale, Peter, 1970, 'Minerals and Metals in Japanese-Australian Trade', The Developing Economies, Vol. 8, No.42, pp. 198-218 (June).

Drysdale, Peter, 1972 (ed.), Direct Foreign Investment in Asia and the Pacific, Australian National University Press, Canberra.

Drysdale. Peter, 1988, The Economics of International Economic Pluralism: Economic Policy in East Asia and the Pacific, Columbia University Press and Allen and Unwin, New York and Sydney.

Drysdale, Peter, 2008, 'Deepening Asian Integration and Regional Cooperation Arrangements’, in Asian Development Bank, Emerging Asian Economies, Manila.

Duncan, Roderick, 2006, 'Price or Politics? An Investigation of the Causes of Expropriation', Australian Journal of Agricultural and Resource Economics, Vol.50, No.1, pp. 85-101.

Dunning, John R. and Sarianna M. Lundan, 2008 Multinational Enterprises and the Global Economy, Edward Elgar, Cheltenham, UK, 2008,

Farrell, D, S Lund and K Sadan, 2008, 'The New Power Brokers: Gaining Clout in Turbulent Markets’, McKinsey Global Institute, July,

Freed, Jamie. 2008, 'BHP plays wait and see on Rio offer' 12 July: http://business.smh.com.au/business/bhp-plays-wait-and-see-on-rio-offer-200807113dr7.html

Garnaut, John, 2008, 'Master of the Universe' The Diplomat, June.

Garnaut, Ross and Anthony Clunies-Ross, 1975, 'Uncertainty, Risk Aversion and the Taxing of Natural Resource Projects’, The Economic Journal, Vol. 85, No. 338 (June), pp. 272-287.

Garnaut, Ross and Anthony Clunies-Ross, 1983,The Taxation of Mineral Rents Oxford University Press, Oxford.

Hanratty P. 1996, Inward Direct Foreign Investment in Australia: Policy Controls and Economic Outcomes, Department of the Parliamentary Library, Parliamentary Research Service, Research Paper No. 32, May.

Hanson, Gordon H, 2001, Should Countries Promote Foreign Direct Investment? UNCTAD, G-24 Discussion Paper Series, UNCTAD and Harvard Center for International Development, No. 9, February.

Hartley, P.R., 1984, 'Foreign Ownership and the Australian Mining Industry' in L.H. Cook and M.G. Porter (eds.), The Minerals Sector and the Australian Economy, George Allen \& Unwin, Australia, Sydney.

Hogan, L. 2007, Mineral Resource Taxation in Australia: An Economic Assessment of Policy Options, ABARE Research Report 07.1.

J.P Morgan, 2008, Sovereign Wealth Funds: A Bottom-up Primer, May. 
Korporal, Glenda, 2008. 'China warns Labor on investment curbs', The Australian, 2 July 2008.

Kloppers, Marius, 2006 'Resourcing Asian Growth’: http://www.bhp.com.au/bb/home.jsp

Kearney, A T, 2007, Foreign Direct Investment Confidence Index, Global Business Policy Council, New York.

Lesbirel, Hayden S. 2004, 'Diversification and Energy Security Risks: The Japanese Case’, Japanese Journal of Political Science, Vol. 5, pp. 1-22.

McKern, Bruce, 1976, Multinational Enterprises and Natural Resources: Foreign Investment in the Australian Minerals Industry, McGraw-Hill, Sydney.

Monitor Group, 2008, Assessing the Risks: The Behaviors of Sovereign Wealth Funds in the Global Economy, New York.

Smith, Ben, 1980, 'Long Term Contract Arrangements and Financing Arrangements for Minerals Developments', Research Paper, Australia Japan Research Centre, No. 72, Canberra, September.

Staff Reporter, 2008, 'BHP warns of Chinese risk if Rio Tinto deal fails', The Business Spectator, 21 July 2008.

Stevens, Matthew, 2008, 'China faces mining investment curbs,' The Australian, 26 June.

Stoeckel, Andrew, 2008, Sovereign Wealth Funds: Friend or Foe, Centre for International Economics, Canberra.

Streifel, Shane. 2006, 'Impact of China and India on Global Commodity Markets: Focus on Metals and Minerals and Petroleum', Background paper for Dancing with Giants: China, India, and the Global Economy, Institute for Policy Studies and the World Bank, Washington, DC.

Swan, Wayne, Australia, China and This Asian Century, Speech to the Australia-China Business Council, Melbourne, 4 July 2008.

Taylor, Lenore. 2008, 'China’s stake in Rio gets all-clear', The Australian, 25 August.

Thirwell, Mark, 2008, 'Sharing the spoils of China's rise means negotiating some tricky investment twists and turns', The Australian, 7 July.

Thornton, John, 2008, ‘Governing China’s Boards: An Interview with John Thornton', The McKinsey Quarterly, August.

Treasury, The Department of, 2008, Budget Papers.

Treasury, The Department of, 1995-2007 Foreign Investment Review Board, Annual Reports, 1995-2007: http://www.firb.gov.au/content/publications.asp?NavID=5

Truman, Edwin, 2008, A Blueprint for Sovereign Wealth Fund Best Practices, Peterson Institute Policy Brief, PB08-3, April. 
UNCTAD, 2007, World Investment Report 2007: Transnational Corporations, Extractive Industries and Development, available from

http://www.unctad.org/Templates/webflyer.asp?docid=9001\&intItemID=4361\&lang=1 \&mode $=$ downloads

Williams, Felicity, 2008, 'BHP Billiton values Rio Tinto smelters', Herald Sun, 20 August.

Woetzel, Jonathan R., 2008 'Reassessing China’s State-Owned Enterprises', The McKinsey Quarterly, August.

Wood, Alan, 2007 'The Sovereign Wealth Fund Game Needs New Rules’, The Australian, 3 November.

Wu, Jinglian, 2008 'The Road Ahead for Capitalism in China', The McKinsey Quarterly, August.

Young, Stephen and Tong Lu, 1998, 'Internationalization of Chinese Enterprises: Key Issues for the Future', Long Range Planning, Vol. 31 Issue 6, Strathclyde International Business Unit, Glasgow, and Institute of World Economics and Politics, CASS, Beijing.

Zhang, Yuxuan and Fan He, 2008, 'China's Sovereign Wealth Fund: Weakness and Challenges’, Research Center for International Finance Working Paper, No. 0823, December. 


\section{Appendix 1}

\section{Principles Guiding Consideration of Foreign Government Related Investment in Australia}

Australia maintains a welcoming stance towards foreign investment in recognition of the substantial benefits that it provides to our community.

The purpose of Australia's foreign investment screening regime is to ensure that foreign investment into Australia is consistent with our national interest. The Treasurer can reject proposals that are deemed contrary to the national interest or impose conditions on them to address national interest concerns.

Significant foreign investment proposals must be notified to the Australian Government and examined by the Foreign Investment Review Board (FIRB). This includes all proposed investments by foreign governments and their agencies. This requirement is a longstanding feature of Australia's foreign investment policy that has been maintained in place by successive governments.

While the FIRB plays an important advisory role, determining whether a proposal is consistent with the national interest is ultimately a matter for the Treasurer. To ensure they are consistent with Australia's national interest, the FIRB examines whether proposed foreign investments may have any adverse implications for Australia's national security or economic development and ensures they are consistent with any specific foreign investment legislation in areas such as transport and telecommunications. It also examines whether proposals have implications for other Government policies, competition and the operations of Australian businesses. If the Treasurer forms a view that a foreign investment would be inconsistent with Australia's national interest, it may be blocked or made subject to conditions to address any problems that have been identified. 


\section{Guidelines for foreign government investment proposals}

Proposed investments by foreign governments and their agencies (e.g. state-owned enterprises and sovereign wealth funds (SWF)) are assessed on the same basis as private sector proposals. National interest implications are determined on a case-bycase basis.

However, the fact that these investors are owned or controlled by a foreign government raises additional factors that must also be examined.

This reflects the fact that investors with links to foreign governments may not operate solely in accordance with normal commercial considerations and may instead pursue broader political or strategic objectives that could be contrary to Australia's national interest.

The Government is obliged under the Foreign Acquisitions and Takeovers Act 1975 to determine whether proposed foreign acquisitions are consistent with Australia's national interest. In examining proposed investments by foreign governments and their agencies, the Australian Government will typically have regard to the following six issues.

\section{An investor's operations are independent from the relevant foreign government.}

In considering issues relating to independence, the Government will focus on the extent to which the prospective foreign investor operates at arm's length from the relevant government.

It also considers whether the prospective investor's governance arrangements could facilitate actual or potential control by a foreign government (including through the investor's funding arrangements).

Where the investor has been partly privatised, the Government would consider the size and composition of any non-government interests, including any restrictions on governance rights. 


\section{An investor is subject to and adheres to the law and observes common standards of business behaviour.}

To this end, the Government considers the extent to which the investor has clear commercial objectives and has been subject to adequate and transparent regulation and supervision in other jurisdictions.

The Government will examine the corporate governance practices of foreign government investors. In the case of an SWF, the Government would also consider the fund's investment policy and how it proposes to exercise voting power in relation to Australian companies.

Proposals by foreign government owned or controlled investors that operate on a transparent and commercial basis are less likely to raise additional national interest concerns than proposals from those that do not.

\section{An investment may hinder competition or lead to undue concentration or control in the industry or sectors concerned.}

These issues are also examined by the Australian Competition and Consumer Commission in accordance with Australia's competition policy regime.

\section{An investment may impact on Australian Government revenue or other policies.}

For example, investments by foreign government entities must be taxed on the same basis as operations by other commercial entities. They must also be consistent with the Government's objectives in relation to matters such as the environment.

\section{An investment may impact on Australia's national security.}

The Government would consider the extent to which investments might affect Australia's ability to protect its strategic and security interests. 


\section{An investment may impact on the operations and directions of an}

Australian business, as well as its contribution to the Australian economy and broader community.

The Government would consider any plans by an acquiring entity to restructure an Australian business following its acquisition. Key interests would include impacts on imports, exports, local processing of materials, research and development and industrial relations.

The Government would also consider the extent of Australian participation in ownership, control and management of an enterprise that would remain after a foreign investment, including the interests of employees, creditors and other stakeholders.

Source:

http://www.treasurer.gov.au/DisplayDocs.aspx?doc=pressreleases/2008/009.htm\&p ageID $=003 \& \min =$ wms $\&$ Year $=\&$ DocType $=$ 